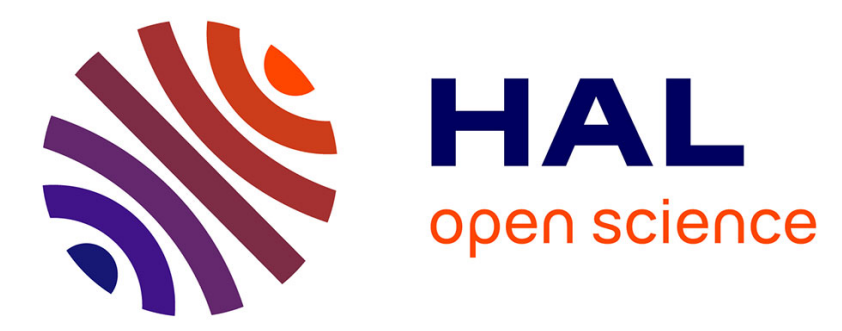

\title{
ENABLING OR INHIBITING THE CREATIVE ECONOMY: THE ROLE OF THE LOCAL AND REGIONAL DIMENSIONS IN ENGLAND
}

Caroline Alexandra Chapain, Roberta Comunian

\section{- To cite this version:}

Caroline Alexandra Chapain, Roberta Comunian. ENABLING OR INHIBITING THE CREATIVE ECONOMY: THE ROLE OF THE LOCAL AND REGIONAL DIMENSIONS IN ENGLAND. Regional Studies, 2010, 44 (06), pp.717-734. 10.1080/00343400903107728 . hal-00600458

\section{HAL Id: hal-00600458 https://hal.science/hal-00600458}

Submitted on 15 Jun 2011

HAL is a multi-disciplinary open access archive for the deposit and dissemination of scientific research documents, whether they are published or not. The documents may come from teaching and research institutions in France or abroad, or from public or private research centers.
L'archive ouverte pluridisciplinaire HAL, est destinée au dépôt et à la diffusion de documents scientifiques de niveau recherche, publiés ou non, émanant des établissements d'enseignement et de recherche français ou étrangers, des laboratoires publics ou privés. 


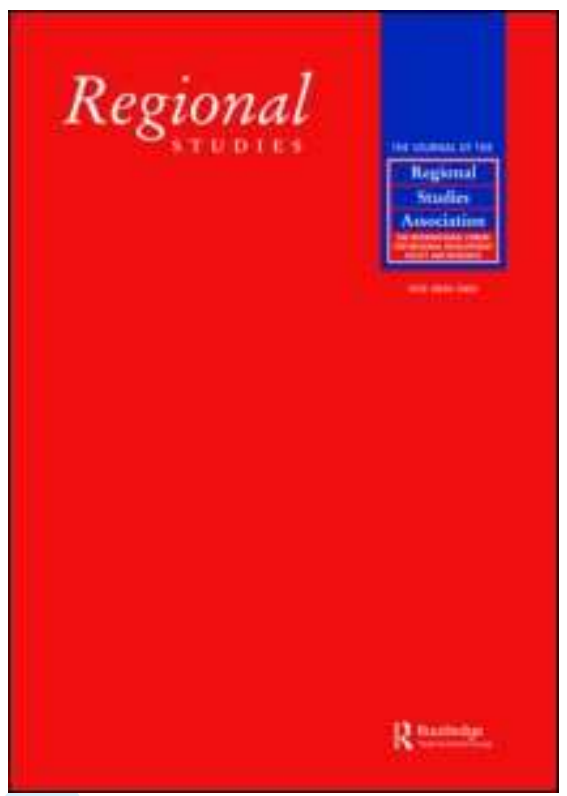

\section{ENABLING OR INHIBITING THE CREATIVE ECONOMY: THE ROLE OF THE LOCAL AND REGIONAL DIMENSIONS IN ENGLAND}

\begin{tabular}{|r|l|}
\hline Journal: & Regional Studies \\
\hline Manuscript ID: & CRES-2007-0251.R1 \\
\hline Manuscript Type: & Main Section \\
\hline JEL codes: & $\begin{array}{l}\text { O18 - Regional, Urban, and Rural Analyses < O1 - Economic } \\
\text { Development < O - Economic Development, Technological Change, } \\
\text { Economic Activity < R1 - General Regional Economics < R - Urban, } \\
\text { Rural, and Regional Economics }\end{array}$ \\
\hline Keywords: & $\begin{array}{l}\text { Creative industries, regional cultural policy, regional economic } \\
\text { development, creative clusters, knowledge pool }\end{array}$ \\
\hline
\end{tabular}

\section{s ScholarONE" \\ Manuscript Central}


ENABLING AND INHIBITING THE CREATIVE ECONOMY: THE ROLE OF THE LOCAL AND REGIONAL DIMENSIONS IN ENGLAND.

Authors:

Dr Caroline Chapain, Centre for Urban and Regional Studies, Birmingham Business School, J.G. Smith Building, Pritchatts Road, Edgbaston, Birmingham, B15 2TT, UK, c.a.chapain@ bham.ac.uk

Dr Roberta Comunian, School of Geography, University of Southampton, Highfield - Southampton SO17 1BJ (UK) E-mail: $\underline{\text { R.Comunian@ soton.ac.uk }}$

(Received August 2007: in revised form December 2008) 


\begin{abstract}
Integrating findings from two separate research projects in Birmingham and Newcastle-Gateshead in England, this paper explores factors that enable or inhibit the development of creative and cultural industries (CCIs) in English regions outside London. Our findings question current CCIs policies and their understanding of the local and regional dimensions as being limited to the idea of geographical clusters. Instead, the paper calls for a wider approach which also takes into account the importance of the regional infrastructure and the "knowledge pool" necessary to the development of CCIs, but also personal and operational connections of the CCIs within and outside their region.
\end{abstract}

KEYWORDS: Creative industries, regional cultural policy, creative clusters, regional economic development, knowledge pool.

对创意经济的促进及制约：地方及区域在英格兰的作用，区域研究。在整合了英格兰伯明翰 与纽卡斯尔盖茨黑德两个独立研究项目结果的基础上，文章探讨了伦敦之外的英国区域促进 或制约创意文化产业（CCIs）的因素。研究质疑了目前的创意及文化产业政策，以及上述政 策中关于地方及区域层面对地理空间集聚产生制约的理解。相反，文章提倡使用一种更具包 容性的方法，不但强调区域基础设施的重要性以及对CCIs产业发展而言必不可少的“知识库” (knowledge pool）的重要性，同时还囊括了CCIs产业在区域内外个人及技术上层面上的联系。 创意产业 区域文化政策 创意集群 区域经济发展 知识库

Cet article intègre les résultats de deux projets de recherche réalisés respectivement à Birmingham et Newcastle-Gateshead afin d'explorer les facteurs qui favorisent ou inhibent le développement des industries culturelles et créatives dans les régions anglaises à l'extérieur de Londres. Nos résultats remettent en cause les politiques culturelles et créatives anglaises actuelles et leur compréhension de la dimension locale et régionale limitée à l'idée de regroupement («cluster ») géographique d'entreprises. Au contraire, cet article recommande l'adoption d'une approche élargie tenant compte de l'importance de l'ensemble des infrastructures régionales et du pool de connaissance nécessaires au développement de ces industries mais aussi de leurs connections personnelles et d'affaire à la fois à l'intérieur et à l'extérieur de leur régions.

KEYWORDS (FRENCH): industries créatives, politique culturelle régionale, économique développement régional, pool de connaissance.

Förderung und Behinderung der kreativen Wirtschaft: die Rolle der lokalen und regionalen Dimensionen in England 


\section{Caroline Chapain and Roberta Comunian}

Anhand der Ergebnisse von zwei separaten Forschungsprojekten in Birmingham und NewcastleGateshead (England) wird in diesem Beitrag untersucht, welche Faktoren die Entwicklung der kreativen und kulturellen Industrie in englischen Regionen außerhalb Londons fördern bzw. behindern. Unsere Ergebnisse stellen die derzeitigen Politiken für kreative und kulturelle Industrie und deren Verständnis der lokalen und regionalen Dimensionen in Frage, da sie sich auf die Idee der geografischen Cluster beschränken. Stattdessen wird in diesem Beitrag ein breiterer Ansatz befürwortet, der auch die Bedeutung der regionalen Infrastruktur und des 'Wissenspools' berücksichtigt, welche für die Entwicklung der kreativen und kulturellen Industrie erforderlich sind, und ebenso die personellen und betrieblichen Verknüpfungen dieser Industrie inner- und außerhalb ihrer jeweiligen Region einbezieht.

\section{KEYWORDS:}

Kreative Industrie, Regionale Kulturpolitik, Kreative Cluster, Regionale Wirtschaftsentwicklung, Wissenspool

Fomento e inhibición de la economía de la creatividad: el papel de las dimensiones locales y regionales en Inglaterra

Al integrar los resultados de dos proyectos separados de investigación en Birmingham y NewcastleGateshead en Inglaterra, en este artículo analizamos los factores que permiten o inhiben el desarrollo de las industrias creativas y culturales en las regiones británicas fuera de Londres. Nuestros hallazgos cuestionan las políticas actuales de las industrias creativas y culturales y su concepto de dimensiones locales y regionales porque se limitan a la idea de las aglomeraciones geográficas. Más bien, en este ensayo pedimos un enfoque más amplio que también tenga en cuenta la importancia de la infraestructura regional y el "fondo de conocimiento" necesarios para el desarrollo de industrias creativas y culturales pero también las conexiones personales y operativas de estas industrias dentro y fuera de la región.

Keywords:

Industrias creativas, Política cultural regional, Aglomeraciones creativas, Desarrollo económico regional, Fondo de conocimiento

JEL classifications: O18, R12, Z10, Z13

\section{INTRODUCTION}

In the past ten years creative and cultural industries (CCIs) have become the focus of policy and academic discussion across the developed world. This has been strongly influenced by English policies where CCIs has emerged as a key aspect of national economic development policy since 1998. The Department for Culture Media and Sport (DCMS) report "Creative Industries. Mapping 
Document" (1998) was crucial in providing a general and operational definition for creative industries. In the document, the DCMS defines creative industries as "those that are based on individual creativity, skill and talent. They also have the potential to create wealth and jobs through developing and exploiting intellectual property. The creative industries include: Advertising, Architecture, Arts and antique markets, Computer and video games, Crafts, Design, Designer Fashion, Film and video, Music, Performing arts, Publishing, Software and Television and Radio.” The DCMS (2000) "Creative Industries: The Regional Dimension" moved this agenda away from Central Government policies into the strategies of the Regional Development Agencies (RDAs). As a result, CCIs have been highlighted as a key element in local economic development in most English regions. Although many research and scoping studies have been carried out during the last seven years, there has been no consistent assessment of the local and regional dimensions of the creative economy. Many studies that look at creative industries at the local and regional levels have focused on measuring their size; however, current quantitative approaches suffer from a lack of appropriate data. In addition, the study of the relationship between CCIs and places has been dominated by the cluster paradigm with a strong focus on firm's co-location. These studies are relevant but they tend to ignore an increasing body of literature, suggesting the importance of individuals and their social networks in the local and regional development of creative industries (COMUnian, 2008). Consequently, few studies of the dynamics of creative industries have yet explored the quality of the interactions that take place in the "creative economy" ecosystem at the local and regional levels.

This paper addresses these issues by exploring the role of the local and regional dimensions in the development of CCIs in two cities and regions in England: Birmingham in the West Midlands and Newcastle-Gateshead ${ }^{1}$ in the North-East. To address this, the paper complements insights from the cluster perspective on firms competitive advantage with a knowledge pool model approach centred on individuals. It details the relationship of the creative industries and location using four main components: personal, operational, networks and public support and the wider regional 
infrastructure. The paper therefore aims to bring an original contribution to the debate about local and regional advantages in the creative economy and provides a deeper understanding of the dynamics of creative industries at local and regional levels by comparing original qualitative data for two English cities.

The structure of the paper is as following. First, the paper critically reviews the current creative economy discourse addressing both national and regional dimensions and linking academic and policy debates (NESTA, 2006). These debates encompass the 'creative clusters' approach which focuses on the firm and has been adopted by RDAs and many researchers in the field. The following section proposes to integrate the cluster approach with a "knowledge pool" perspective, in order to provide new centrality to the role of individuals and their social networks in understanding the practice of CCIs at the local and regional levels. The methodology and the case studies are presented in section four. Section five details our findings and explores the role of place in enabling and inhibiting CCIs across the four different levels identified earlier. Finally, conclusions are drawn with regard to the potentials and the limitations of the local and regional dimensions, comparing Birmingham and Newcastle-Gateshead.

\section{THE CREATIVE ECONOMY DISCOURSE AND THE LACK OF EVIDENCE AT THE LOCAL} AND REGIONAL LEVELS IN ENGLAND

Since the first Creative Industries Mapping Document (DCMS, 1998) in England, many authors have addressed the rise of CCIs in the national public policy agenda and its implications (PRATT, 1997; O'CONNOR, 1999; GARNHAM, 2005). More recently, CCIs have become one of the foci of local and regional development strategies (TUROK, 2003; PRATT, 2004c; JAYNE, 2005; OAKLEY, 2006), often with limited understanding of the dynamic of these industries at the sub-national levels. Cultural differences, path dependence as well as variations in the economic potential of local and regional CCIs have largely been ignored. This has often resulted in replications of policies and 
strategies from the national to local and regional levels. Some economic strategies and policy interventions have focused on specific assets and infrastructures which a city or a region should provide to enable it to be or to become a "creative city". Initially, attempts were made to link wider regeneration projects and urban interventions to the creative economy. Then, influenced by the cluster approach, the focus shifted to more narrow interventions such as new investments in cultural facilities and development of support programmes aimed at CCIs. As pointed out by Oakley "no region of the country, whatever its industrial base, human capital stock, scale or history is safe from the need for a 'creative hub' or 'cultural quarter' " (OAKLEY, 2004, p.68).

The 2000, DCMS report “Creative Industries: The Regional Dimension" tried to move beyond the statistics by conducting interviews with local stakeholders, and was thus a seminal qualitative contribution to the understanding of the regional dynamic of creative industries. It also raised a number of regional issues. However, this exercise has not been repeated since. The 2001 DTI report "Business Clusters in the UK - A First Assessment" also provided some quantitative information on the regional distribution of CCIs. Since then, studies of the local and regional dimensions have been more limited and controversial. The 2004 "DCMS Evidence Toolkit" mentioned the lack of coordination and strategic thinking at the regional level and showed how methods and practice have not really moved forward in the last decade (CREIGHT-TYTE, 2005). This is mostly due to the weakness of nationally available data - making it difficult to include and to understand all creative sub-sectors within the broader 'creative industries' framework ${ }^{2}$.

Nevertheless, most RDAs and local bodies have produced evidence or advocacy regarding the role and dimension of CCIs in their regional economy ${ }^{3}$. Authors including Pratt (1997), Creight-Tyte (2005) and Taylor (2006) have stressed the lack of consistency in methodologies along with the general issues of what can be and what should be measured. Comparisons in time and space have been made impossible by the use of different definitions and methods. These methodological difficulty and inconsistencies make it very difficult to understand how local and regional dynamics of the creative industries contribute to the national development of such industries. 
This raises the question: What is our real understanding of regional creative economies, in terms of both their weaknesses and their strengths, today? What are the practices and discourses experienced at the local level from people working in this sector?

Methodological limits and fragmented frameworks might also hide the fact that the creative economy is a success story only for a few regions. The detailed picture of the regional dimension given by Pratt in 1997, although dated, suggests a large disparity between London and the South East - regarded as the creative hub of the country - and the rest of UK trying to catch up with it. Questions can be raised as to whether this gap has been reduced, or indeed widened, over the last ten years. Oakley (2006, p.267) has documented the still undeniable weight of London and the South East in the national creative economy: "these two regions account for 46 per cent of the creative workforce compared with 27 per cent of the total UK workforce". Furthermore, the author shows how this predominance is even more visible when looking at the percentage of turnover represented by London-based firms. Outside the South and East "there are other isolated cities that have had positive rates of change, but the regional effects of these appear weaker". (OAKLEY, 2006, p.268)

However, Jeffcutt and Pratt (2002) have suggested that while much of the attention in the research with regard to CCIs has been focused on the macro level (comparing cities and their capabilities and labour market in the creative economy) and meta level (analysing the long-term impact of CCIs as a knowledge economy) there is a need for a better understanding of what goes on at the micro and meso levels. This is the objective of this paper, which addresses the importance of a better understanding of the relations of CCIs within the city and the region; for example, the role of personal attachment to the place, the dynamics between agencies and other actors and the role of the network infrastructure underpinning creative practitioners' work. In order to do so, the next section discusses the current usage of the cluster approach to understand and foster CCIs at the local and regional levels. As an alternative to this approach, it argues for the use of a wider framework which integrates the cluster approach with the creative knowledge pool (CURDS, 2001). 


\section{FROM CREATIVE CLUSTERS TO A CREATIVE KNOWLEDGE POOL}

Most authors looking at CCIs at local and regional levels have used some kind of cluster approach, on the basis that clustering plays an important role in these industries. For example, Scott (2000; 2002; 2005) and Storper (STORPER and CHRISTOPHERSON, 1987; STORPER, 1989) have specifically developed their studies in the context of cultural clusters, i.e. the development of the film industry in Hollywood. Many other authors have focused on the analysis of clustering in different sectors of CCIs (Table 1) and have used this paradigm to understand and support CCIs.

In the UK, influenced by the work of Porter (PORTER, 1998a, 1998b) the cluster approach has been part of the national economic development agenda since the end of the 1990s (DTI, 1999). With the creation of the RDAs, the approach has been brought to the regional scale in order to capture the added value of the creative economy in a cohesive way (JAYNE, 2005; OAKLEY 2006). An important emphasis has been placed on the infrastructure of clusters, in an attempt to engineer their development and implementation. However, this policy approach has often been short-sighted in respect to problems such as gentrification or the lack of sustainability and social capital development, as if co-location or the co-presence of CCIs could itself determine economic development and success.

The cluster model is undoubtedly important to the understanding of the relations between CCIs and the regional dimension. In particular it successfully articulates firm strategy with the role of demand, local competition and factors endowment (labour, capital...) as well as other related supporting industries and conditions such as research institutes or public agencies. Nevertheless, the present paper argues for a need to integrate it with a 'knowledge pool' perspective in order to overcome some of the limitations of the model - when applied to the CCIs sector, in particular the role of creative individuals and their social networks - and to provide a better understanding of the centrality of the relational perspective that is social processes and relationships (BATHELT AND GLÜCKLER, 2003) in the creative economy. 
The concept of cluster as "geographic concentrations of interconnected companies and institutions in a particular field" as defined by Porter (1998a, p.78) has been questioned in reference to its undefined geographical scale (MARKUSEN, 2003; MARTIN AND SUnLEY, 2003). This is especially true in the context of CCIs where it is possible to find smaller concentrations enclosed in a single building (such as the Custard Factory in Birmingham), specific areas of the city (such as the Ouseburn Valley in Newcastle or Birmingham Jewellery Quarter), but also some more abstract regional cluster initiatives were boundaries are not easy to define. In these terms, clustering as physical co-location of activities can provide a very limited understanding of how relations and exchanges take place in a specific context. The cluster approach might be an easier strategy for public policy intervention as the beneficiaries are enclosed in specific geographical locations. However, some of the activities crucial to the cluster can often been based outside these geographical foci.

Another limit of the cluster paradigm consists in focusing mainly on the value-chain of one category of products or activities. On the contrary, in the CCIs it is difficult to identify a single category of products associated with one value-chain, such as a film, a performance or a book, as creative content may generate or be used in a variety of different products or activities. Consequently, creative practitioners and companies tend to use their skills in different creative subsectors. Project work is an important component of some of these sub-sectors and requires significant collaboration across sub-sectors for specific period of time. These collaborations change constantly depending on projects. These cross-sectorial exchanges of knowledge and individuals' career portfolios are not easily captured by the cluster model, which usually focuses on the relationship of firms engaged in specific and narrow supply chains with specific and specialised knowledge. 
That is why CURDS (2001), building on the idea of knowledge community developed by HENRY AND PINCH (2000), argues for the use of a knowledge pool model focusing on individuals to study creative industries. This perspective is not in complete opposition to the cluster approach, but is more flexible in its understanding of the role of creative individuals and their relationship to place. In fact, the model allows for a better understanding of the role of other 'soft infrastructures' such as networking, atmosphere and local scenes in the production of culture and creative goods.

In addition, the model proposes a new centrality of the creative individuals and highlights the need to further investigate their relationships with one another and with the locality. Many authors (for example Mossig, 2004; Kong, 2005) underline the importance of trust in building stable interactions and/or networks as a base for flexible specialisation. However, trustful relationships cannot be immediately born, but are the result of continuous interactions. They are built on positive past transactions and experiences. The importance of networks as a soft infrastructure fostering economic development has been emphasised in the recent literature (GRABHER, 2001; WITTEL, 2001; GrabHeR, 2002; ETtLinger, 2003; GRABHER, 2004; KonG, 2005; LANGE, 2005) but has only recently been introduced at policy level, with varying degrees of success. This has been true for some of the policies adopted by Newcastle-Gateshead and Birmingham, on which this article focuses.

This soft dimension is particularly important in linking cultural and creative production and place but is often considered as a given factor that cannot be rationalised in the creative cluster approach (O'CONNOR, 2002). As Pratt (2004a) highlights, the concept of cluster fails "to capture the broader spatial, temporal and organisational dynamics of production across creative industries" and there is the "need to construct an evidential base of information about inter-firm transactions of both material and non-material, economic and non-economic character [...] the potential is to develop both an understanding of the dynamics as well as the way in which particular localities are implicated within the production systems" (PRATT, 2004a, p.21) 
Therefore, rather than only considering the importance of the clustering dimension of creative firms, it seems more important to focus on the wider system that enables and supports the development of creative individuals and their activities in a specific urban and regional context. Therefore, the present research proposes to bridge the cluster approach - centred on firms activities - with the Creative Knowledge Pool model developed by CURDS (2001, fig. 1), which has individuals at its core.

To do so, we propose a reinterpretation of the knowledge pool model highlighting some of the theoretical underpinnings of the cluster approach. At the heart of the model are the creative individuals with their skills sets and knowledge. These individuals are either self-employed or part of creative firms and come together through projects or venues (CURDS, 2001). The arrows linking different actors in the model represent different interactions and relations. These can be financial relations, knowledge and information exchange, contracts and partnerships. The model is over simplifying the complexity of these interactions but for any different business or in different sectors of the creative economy some of these interactions will be present and very important, some others will be less deep or relevant.

Based on our interpretation of the model, it seems possible to distinguish four layers of interactions, which are relevant to an understanding of the local and regional dimension of the creative economy. Some are based on individuals and some are based on firms. These layers are not specifically linked to a geographical scale and are not meant to define and fix the amount or meaning of the interactions of all CCIs in a specific context. They are used as an analytical tool to unfold the different nature of interactions and actors participating in the creative knowledge pool in any chosen context. Some CCIs have a strong connection with cultural and creative support agencies; others hardly interact with them; for some CCIs direct contact with audiences through venues is a key part of their production, while for others the norm is business to business interactions. Therefore, this model can be used as flexible tool, which will enable the research to unpack relations and actors and study their interconnections. In the analysis of the CCIs of Birmingham and Newcastle-Gateshead 
the four identified layers are used to analyse the relations between CCIs and place. Moving from the creative individual, at the core, to the firm, to the networks of creative individuals, companies and sectorial supporting agencies and finally to the wider context of the urban and regional environment and the general supporting agencies and other services.

In the first layer (the central circle) the focus is on the relationship between creative individuals and the place in which they live. This personal dimension is often characterised by emotive aspects, linked to the personal history of the individual. This level also relates to the role that place can have as source of inspiration and creativity (DRAKE, 2003).

The second circle specifically addresses the employment and work opportunities that a place can offer; looking at the business and employment perspective of creative practitioners and companies. This level relates to the cluster approach where firms strategy, structure and rivalry as well as the demand and factors conditions can be key factors of development of creative companies. At this level, local specialisation and the presence of a cluster can influence the possibility of people being employed or developing a business. These dynamics are also important for temporary project-based and freelance work (GRABHER, 2001; MCROBBIE, 2002; PRATT, 2004b).

The third layer introduces the relationship between creative individuals and firms with those actors which actively engage with the creative economy: specialist business services for CCIs, local and regional networks and associations of CCIs and venues and other CCIs support agencies. At this level, the relationships and connections between companies become very important. This level relates both to the concepts of "related and supporting industries" as well as "government" developed by Porter (1998a) and to the concept of social networks, which are important for creative individuals. Often the emergence of local clusters or cultural quarters is linked to growing interactions between this layer and the second layer. Finally, the fourth circle includes the larger non cultural infrastructures as well as actors and organisations that have looser relationships with the creative economy, but can still be important elements of the local and regional supply-chain or production system (PRATT, 1997) or of the CCIs ecosystem (JEFFCUTT, 2004) such as 
transportation, universities, access to markets, retailing, image and reputation of the city etc. This level relates to some of the demand and factors conditions and chance as defined by Porter (1998a) but goes beyond Porter's approach by evaluating the impact that these factors can have on individuals in general. The third and the fourth layer may be closely intertwined in regard to policies.

Finally, this model does not imply that the geographical scale is limited to local and regional interactions. In fact, many authors have investigated the role of multi-scalar relationships in the creative economy and especially their global dimension (COE, 2001; COE and JoHnS, 2004; SCOTT, 2004). Nevertheless, the focus of the present research is specifically the role and the dynamic aspect of the local and regional dimensions.

\section{>> INSERT FIGURE 1 HERE $<<$}

Drawing on this model, this paper addresses the following research questions:

1. What emotive and creative aspects of the local and regional dimensions are important in terms of the creative individuals' engagement with place?

2. What local and regional operational advantages and disadvantages are important in the development of creative businesses?

3. How relevant and important are factors such as networking and collaboration with other local and regional companies, creative practitioners and specialist supporting agencies?

4. How does the wider local and regional infrastructure such as universities, general policy support, transportation systems, etc. and local and regional sectorial strength and/or critical mass influence the development of creative industries? 
This paper integrates findings from two research projects developed independently but investigating similar aspects of the local and regional dimensions of creative industries in England. By doing so, it generates new understandings of the factors that enable and inhibit CCIs locally and regionally.

The first research project (Birmingham, West Midlands) was commissioned by Birmingham City Council and formed part of the ERDF Creative Knowledge Creative Companies (CKCC) programme. The research was carried out to provide policy makers and practitioners in Birmingham and beyond with a better understanding of the growth dynamics of the creative industries in the city by looking at their business profile, firm performance, firm history, products and processes, customers, knowledge inputs, skills and training, support and co-operation and business support (BURFITT et al., 2005) ${ }^{4}$. The research included 31 interviews with creative entrepreneurs conducted in 2004-2005.

The second research project (Newcastle-Gateshead, North East), was independently conceived and carried out in 2005-2006. This project included 136 interviews with local creative practitioners and people working in the cultural sector, not only in the private but also in the public and not for profit sector, in the region. The central focus of the research was on the importance of place and networks in the creative economy, using both qualitative interviews and social network analysis ${ }^{5}$.

Both research projects used a mixed-methodology approach, but the present paper only focuses on the material from the qualitative side of the studies - the interviews. These qualitative interviews provide a very rich collection of material. Nevertheless, qualitative data also present many challenges in terms of analysis. The problem arises from the sampling, where respondents are often selected on the basis of being well-positioned in relation to the theme that the research is investigating (BAXTER AND EYLES, 1997). Another problem experienced during interviews is how to assess embeddedness (OINAS, 1999). This is absolutely central to the investigation of the role played by the local and regional dimensions in the creative economy and to the problem of 'multivoiceness'. Interviewing a creative practitioner in a firm, instead of the managing director of the same company, may provide a completely different outcome in terms of the experience and 
opinions collected. Furthermore, the importance of project-based and freelance work in the creative economy often leads to one person covering a variety of jobs and roles.

In the present case, these issues have been addressed in different ways. First, interviews in Birmingham focused on creative individuals in decision-making positions, such as managers, directors, partners, sole traders, freelancers; the data from Newcastle-Gateshead were extracted from a comparable sample of interviewees. In addition, interviewees cover the wide range of creative sub-sectors present in both cities. Secondly, findings have been drawn using an induction approach looking at common and specific themes emerging from the interviews in both cities rather than responses to specific questions. ${ }^{6}$ Notwithstanding these issues, the paper proposes a sound comparison of original findings.

\section{CITY AND REGIONS: THE CASE OF BIRMINGHAM IN THE WEST MIDLANDS AND NEWCASTLE-GATESHEAD IN THE NORTH EAST}

The cities of Birmingham and Newcastle-Gateshead present an interesting setting for studying the importance of the local and regional dimensions in the development of CCIs. There were around 1 million inhabitants in Birmingham in 2001, and 5.3 million in the West Midlands. These figures were twice the size of those for Newcastle-Gateshead and the North East respectively. However, each city represented about $18 \%$ of the population of their region and between $20 \%-26 \%$ of the region's employment. A rough estimate suggests that in relative terms (expressed as the proportion of creative jobs in the local economy), the importance of the creative sector in Newcastle-Gateshead is closer to the national average than in Birmingham (LUTZ et al., 2007). Both cities have undergone major regeneration in the last 20 years involving various creative sub-sectors, and have more recently put more emphasis on developing the sector. Although neither is part of the London and South East creative hub, Birmingham benefits from fast transport connections and interactions with the capital, whereas Newcastle-Gateshead faces issues related to its peripheral geographical 
and economic setting in the national economy. This section provides a brief portrait of the two cities in terms of their recent policy engagement with the creative economy.

Birmingham.

The 1970s and 1980s saw a major decline in manufacturing in the West Midlands, and the city of Birmingham was severely affected. In order to cope with this economic challenge, an ambitious strategy of economic regeneration transformed the industrial/financial/service base of Birmingham in the 1980s and 1990s. Although there have also been recent attempts to diversify its industrial base by developing new, high value, high growth activities such as telecommunications, pharmaceuticals and computer software/hardware services, Birmingham remains at risk because of the continuing over-dependence on low-value manufacturing sectors and due to declining employment linked to the fragile automotive industry.

Nonetheless, the city's engineering and design heritage has remained strong and Birmingham has seen an increase in the role of CCIs. Since the mid-1990s, Eastside and the historic Jewellery Quarter have slowly emerged as significant concentrations of smaller creative businesses and organisations. The latter, still one of Europe's largest clusters of jewellery-related businesses, has experienced diversification into related design industries and sectors such as architecture and advertising. Eastside, the focus of the city's largest current regeneration programme, is emerging as a centre for multi-media activities, graphic design, visual arts and music production and performance.

The last five years have brought improvements in terms of coordination and understanding of the creative industries, although the sheer number of organisations involved in the sector does not make the task easy. Key agencies such as the Learning and Skills Council, former Birmingham and Solihull Business Link, Advantage West Midlands, Arts Council West Midlands plus those representing creative sub-sectors such as Screen West Midlands, have come together to deliver joined-up thinking. This has been expressed in a variety of regional and local documents and 
research but also in the recent recognition of the Jewellery Quarter as a creative quarter in the City Master Plan.

However, it is still difficult for some of the local or regional institutions to really understand what the creative industries are about. This may be due to the different mindsets of policy makers and creative people, but also to the past development of the city. Birmingham has always been oriented towards business and manufacturing. The strategy in the 1980s and1990s was easier to implement because there were still links with this image, for example, in the approach to the development of business tourism. Consequently, some policy makers still have difficulty believing that they are not investing in something 'risky' because creativity is not always rewarded by huge amount of money or success (BROWN et al., 2007).

Newcastle-Gateshead.

In the context of Newcastle-Gateshead and the North East the new emphasis and attention towards the creative economy can be linked to a long process of cultural regeneration in the region. This process started in the early nineties when the region attracted the Year of Visual Arts, held in 1996. The ability of some regional actors (lead by Northern Arts, now the Arts Council North East) to attract large public investments to the region in order to revitalise the local economy and to develop local participation in arts activities are widely acknowledged (BAILEY et al., 2004). These investments enabled the creation of large publicly funded cultural infrastructures, not only in contemporary art (The Baltic) and music (The Sage Gateshead) but also in theatres (refurbishments of the Northern Stage, Theatre Royal and Live Theatre), crafts (National Glass Centre, expansion of the Shipley Gallery), literature (Seven Stories), dance (Dance City) and other important events. The question of whether and to what extent public sector infrastructure benefits the local creative economy is not a simple one to address. Nevertheless, the region and specifically NewcastleGateshead are considered to have benefited from a 'brain gain' (MINTON, 2003) and is for the first time listed as a 'creative city'. 
At the beginning of the 2000s, the RDA, local authorities and support agencies started looking at the potential economic impact of the creative economy locally and regionally ${ }^{8}$.

The idea of developing a 'cultural quarter' strategy has been quite strong - although criticised (SHORTHOSE, 2004) - and has involved different actors. In particular, at the marketing and promotional level, a first formulation of the 'cultural quarters' map of the city was developed by the Newcastle-Gateshead Initiative (NGI), the city destination agency. In this first presentation five cultural quarters ${ }^{9}$ where included: the Quayside, Grainger Town, the Haymarket, Chinatown and Jesmond. The interpretation of what a 'cultural quarter' is was based mainly on the consumption of culture either through the presence of large cultural institutions or trendy shops. In this classification, no mention was made of the Ouseburn Valley, the largest co-location of artists and creative practitioners in the area. Since 2002-3, a second 'cultural quarter' strategy has been led by the University of Newcastle, which developed a new master plan and major refurbishment initiative for its cultural facilities but also addresses the role of cultural production (specifically through the Culture Lab and the Northern Writer's Centre).

More recently, a wider focus has been developed, not based on clusters but on networks and subsectors. Agencies such as Codeworks (for media industries), Northern Film and Media (for the moving image sector) or New Writing North (for writers) and others have been in charge of developing schemes and training to boost the local creative economy.

However, some challenges remain. Recent research commissioned regionally by Northern Film and Media on the moving image sector stressed the problematic understanding of the creative economy. While RDAs are generally focusing on measuring the economic impact, the report suggests that "90\% of the SMEs surveyed have no commercial goals [...] individuals in each firm are often highly entrepreneurial, most currently choose to apply that talent to building cultural or social capital rather than making money (NORTHERN FILM \& MEDIA, 2004, p.7). 
A QUALITATIVE LOCAL AND REGIONAL PERSPECTIVE ON THE CREATIVE ECONOMY: FINDINGS AND RESULTS

Findings and results from the interviews in the two cities are presented according to the four levels of understanding introduced previously. These four levels are based on a combination of the cluster and the knowledge pool approaches and relate to: personal dimensions that link creative individuals to place; operational advantages and disadvantages relevant to their work and business (firms); networks, collaboration and social capital, and specific policy support and the larger local and regional infrastructure.

\section{Creative Practitioners, Place and the Personal Dimension}

One of the overlooked dimensions of the cluster approach relates to the personal relationship of individuals with the place they live in as expressed by Drake (2003). Our findings show that for both cities and regions, this dimension is relatively important, although it may play a slightly different role depending on the city (Table 2).

There is a strong connection between individuals and place at a private and/or professional level. Many interviewees are natives of the city in which they are now based and proud of it. The presence of universities and colleges also plays a role in linking people to the place. Some creative practitioners studied in both cities, stayed afterwards and/or returned later on. This emerged clearly from the interviews conducted in Birmingham.

This attachment to both cities is also linked to their social capital and, in general, to the sense of identity and community in the place. In Newcastle-Gateshead, many respondents mentioned the inspirational role of place in terms of its people, its cultural assets and its industrial past. With the recent regeneration, both localities are seen as "buzzing". One aspect which emerged strongly in Newcastle-Gateshead is the importance of the local quality of life, such as access to nature and culture, pace of life and work... 


\section{$>$ INSERT TABLE 2 HERE $<<$}

\section{Operational Advantages and Disadvantages}

The operational advantages and disadvantages of a place are usually key factors in the location decision of businesses - they are key components of the Porter model. These factors include operating costs, competition, availability of specific skills in the labour market, appropriate premises, market, etc. These play a role in the location decisions of creative individuals and companies (Table 3). One significant finding is the fact that creative individuals and companies clearly position themselves and their location in Birmingham and Newcastle-Gateshead as opposed to being located in London. The interviews in Newcastle-Gateshead expressed a complex relationship with the capital, regarded as the centre of the creative economy. In Birmingham this issue was present, albeit to a lesser extent because of the geographical proximity with London.

For example, one of the major advantages of being located in Birmingham or Newcastle-Gateshead related to their lower overhead costs compared to London. Both cities draw a necessary amount of activities and have specific markets. Being outside London allows companies and individuals to appear distinctive. They may face less competition locally or regionally. However, linking with the capital is often necessary to the development of their activities in terms of funding, critical mass, facilities, keeping up to date, image...

Parallel to this, creative practitioners/firms sometimes have difficulty obtaining work due to the image of being located in a 'region' or because the critical mass of activities in some sectors is located in London and the South East. London is also perceived as a gatekeeper in many of these sectors - filtering products and producers that can achieve national and international recognition and competition remains strong. Therefore, not being visible in London means being excluded from many career opportunities and ultimately the creative market.

In terms of the creative production system (PRATT, 1997) some facilities and specialised companies are present in Newcastle-Gateshead, but it is still not possible for them to rely purely on local 
facilities or networks, in particular for some specialised services; the links with London thus remain fundamental to deliver their final products. In the case of Newcastle-Gateshead, the distance from the main creative hub is considered a disadvantage, specifically for those sectors which might need a strong initial investment in developing products such as films.

\section{$>>$ INSERT TABLE 3 HERE $<<$}

Both cities also display specific operational advantages or disadvantages. Birmingham has an important Black and Minority Ethnic (BME) community; a third of the population was non-white in 2001. This has an impact in terms of creative industries with the development of BME creative products and services which have a local and regional audience. Examples include the newspaper the Sikh Time for the Sikh community or the Music venue the DRUM and the radio New Style Radio which target the African and Caribbean communities. This phenomenon has also been documented by Burfitt and al. (2005).

Other operational advantages relate to the specific creative sub-sectors where the interviewee is working. Birmingham has had a long tradition of jewellery makers with the presence of a national "Jewellery quarter" where many jewellery companies have clustered. In the case of NewcastleGateshead, drama and film companies find a certain operational advantage in the kind of settings the region can offer. Glass artists also see advantages in the regional glass tradition, particularly around Sunderland and the National Glass Centre.

The geographical and transportation positions of both cities and regions can create some operational advantages. For example, Birmingham is located in the centre of England and has a very good transportation system, which contributes to the operational advantages of the city. On the contrary, the proximity of Newcastle-Gateshead to other centres of cultural production, such as Edinburgh or Manchester, is considered meaningful for the operational activities of some companies. 
Nevertheless, Newcastle-Gateshead presents some operational disadvantages in terms of access to markets and in the way the local demand fails to stimulate sophisticated and high-value production.

\section{Networking and collaboration}

As discussed previously, CCIs are mainly composed of self-employed individuals and small and medium sized enterprises and tend to work on a project basis, therefore establishing connections with other creative individuals, firms and public support agencies is fundamental. This social element is a key element of the knowledge pool model. In this section, we assess the extent of networking for CCIs in both cities (Table 4).

> INSERT TABLE 4 HERE $<<$

As expected, networks are seen as crucial in terms of work opportunities made available by interviewees. They are a powerful instrument through which work is passed on and commissioned. Consequently, networking is seen as a fundamental skill to access the local market and to allow the company to establish itself locally. Increasingly aware of this, support agencies in both cities have recently developed some formal networking events to foster exchanges between practitioners in the same sector, but also across sectors.. Informal networks are linked with social dynamics such as friendship and exchange of information in social environments such as cafes, pubs... In both cities, the social dimension seems to be fundamental and knowing the people you work with and establishing long term relationships is central to the creative production process.

In the case of Newcastle-Gateshead many of the respondents stress how the people working in the sector tend to all know each other. The local creative-cultural economy seems like a large family, a community or a village dimension with strong and frequent interactions. In Birmingham, this is 
particularly true for some sectors like Design, Architecture, Performing Arts, Screen Media and Radio and Jewellery.

When addressing the importance of networks and collaboration, there is certainly the idea that colocation can play a role in facilitating networks and communication thus the importance of the cluster concept developed by Porter; this is specifically true in the case of the Jewellery Quarter and Eastside in Birmingham or the Ouseburn Valley in Newcastle-Gateshead. However, collaboration is also very important across the entire city, regionally, nationally and internationally. Practitioners and companies are usually embedded in multi-scale networks as defined by Coe (2000). There is also a strong commitment to being part of multiple networks, as different kinds of networks can prove important under different perspectives. Some networks are more about collaboration and other about exchanging information albeit in a competitive environment.

Although these strong social and working connections provide a positive environment, they may also create some lock-in effects (as stated by some practitioners in the case of NewcastleGateshead) where the system tends to be less open to outside influences and new inputs.

The regional infrastructure: image and investments

This section explores the role of the wider regional infrastructure in the development of creative activities in both cities (Table 5). This refers to infrastructures such as universities, research and technological centres, cultural facilities, transportation systems and architecture as well as softer measures like public and private support and regeneration schemes, and more intangible elements like the city image and regional identity.

In both Birmingham and Newcastle-Gateshead, extensive investment in infrastructures and regeneration in the last decade are said to have played a major role in enabling the development of creative industries. This has usually been associated with the construction of cultural facilities or flagship developments. As a result, both cities are seen as experiencing a kind of "buzz" and their image has been changing. As already mentioned in section 5.1, this has had an impact on creative 
individuals at a personal level. Interestingly, these changes appear to have an impact at a professional level as well.

For example, some of the new cultural infrastructures and facilities have played an important role as creative incubators. Combined with the critical presence of college and university training programs, this has created a critical mass in some sectors such as Classical Music, Dance and Film, TV and Radio in Birmingham

These processes have been enhanced by a strong intervention of the public sector in terms of support programmes. Influenced by the "creative cluster" and "creative city" paradigms, local and regional actors have put more emphasis on providing business support to creative individuals and companies in recent years. Local and regional public procurement has also been an important source of revenue for some companies, sometimes sustaining the more creative part of their work.

\section{$>$ INSERT TABLE 5 HERE $<<$}

More generally, some creative people have the feeling that this is Birmingham and NewcastleGateshead's turn in terms of creative and economic development. However, there are still challenges to overcome like a certain lack of understanding of the sector by public actors in terms of its social versus economic contribution. Sometimes, practitioners feel that the support available is inadequate and not responding to their specific needs. For example, one major issue is that there is plenty of money for start-ups but less for future growth of more mature companies. In addition, both in Newcastle-Gateshead and Birmingham, some creative practitioners mentioned the concentration of financial resources among a small group of organisations. This emerges clearly in Birmingham.

Finally, in both cities, there is a problem of image. In Newcastle-Gateshead, people still perceive a kind of stigma with regard to the region and its remoteness, compared with the South of England. This affects the way in which they operate and their ability to attract clients and productions. In Birmingham, companies have to fight against the perception that creative quality is in London; 
Birmingham is perceived slightly "cheesy". Consequently, some companies try to mask their geographical location to counterbalance this effect.

\section{CONCLUSION}

The paper has contributed to the understanding of the role of the local and regional dimensions in the development of CCIs by presenting a comparison of original qualitative findings on the experiences of creative practitioners in two cities and regions in England: Birmingham and Newcastle-Gateshead. The paper has argued for the use of a knowledge pool model (CURDS, 2001) in combination with a cluster approach to provide a better and wider understanding of the relationship between creative individuals and their activities and the place along four dimensions: personal, operational, networking and the regional infrastructures.

\section{Creative enablers and inhibitors in Birmingham and Newcastle-Gateshead}

Although the local and regional dimensions need to be understood as one of the multi-scale levels impacting on the work of creative people, both practitioners in Birmingham and NewcastleGateshead stress the importance of place and its complex influence on their activities. Interestingly, our findings suggest strong similarities in the relationship between creative individuals and the two cities and in the way they have tried to enable the growth of the CCIs locally. Nonetheless, both cities and regions also display strong specificities determined by their location and economic strengths (Table 6).

First of all, the personal attachment and social embeddedness of creative individuals play an important role in the location of creative practitioners in both cities and is a strong reason for the development of the creative activities locally and regionally. This personal dimension is often underplayed in the development of creative industries and relates more broadly to the importance of soft location factors. In this sense, recent regeneration policies and public investment in infrastructures have played a key role as enablers for the attraction and retention of creative 
individuals in both Birmingham and Newcastle-Gateshead. This is true for cultural facilities but also for transportation and other types of investment.

Both cities are seen as vibrant and "buzzing", thus a good place to be as a creative individual. Simultaneously, almost in contradiction, some individuals moved to these cities because they are slightly backyard and less hectic than London. The location of Birmingham in the middle of England and its good transportation system also makes the city attractive. Many creative people in Birmingham proudly states they are "born and bread" in the city whereas creative people in Newcastle alludes to the quality of life and the "creative feel" of the place.

Secondly, both cities and regions present substantial operational advantages and enablers of creative activities. In particular, lower overheads and running costs characteristic of a location outside London and the South East are extremely important. In addition, being located outside London enables creative practitioners to be distinctive and "bigger fishes in a smaller pond", with less competitors. Nonetheless, these advantages are balanced with the need for a lively cultural demand or environment and a good connectivity to national and international markets.

The relationship with London is a complex one. In some respect, it seems to impoverish the regional landscape rather than generate positive synergies that could reinforce a national and interconnected creative system. In particular, being located in London is considered to be a warranty of quality for creative work, making it difficult for companies outside the capital to get established. Consequently, local and regional talents based outside London may not be sufficiently exploited. This represents a limit both for the cities and regions concerned but also for national policy framework, which has aimed to promote the recognition and export of creative productions from England.

Some local and regional specific advantages slightly counterbalance this effect, for example the presence of the jewellery cluster and a strong black and ethnic population in Birmingham and a strong visual arts cluster and the proximity to Scotland in Newcastle-Gateshead. 
As discussed previously, one of the advantages of the knowledge pool model is to take into account the importance of the creative individuals and their social networks. The importance of networking emerges strongly from the interviews in both Birmingham and Newcastle-Gateshead. On one hand, local and regional universities, research centres and the sector's formal and informal networks play an important role in connecting creative practitioners with each other and with their local and regional markets. In addition, the mix of institutional and informal networks is important to guarantee the free flow of ideas as well as fulfilling the need for structural advice and business support. Some of the results suggest that the city/region is a place for cooperation, not just competition. In this respect, the characteristics of local and regional networks play a crucial role in linking people to a specific place and its activities. On the other hand, our findings also highlight the importance of multi-scale networks for creative practitioners, challenging a purely local and regional clustering approach. The degree of international connections appears to be stronger for creative practitioners in Birmingham while this may be slightly inhibited by a form a lock-in effect in Newcastle-Gateshead.

Finally, our findings suggest a mixed picture in terms of the role of local and regional infrastructure as enabler and inhibitor. In both cities and regions, local and regional policy makers have shown an undeniable commitment to develop the creative industries. This has been reinforced by significant urban regeneration processes. The presence of three universities has been quite influential in Birmingham in terms of attracting and sustaining creative activities, whereas the strong regional identity of the North-East, recently symbolised by the Angel of the North, has also created a strong creative feeling. Nevertheless, the complex system of interactions underlying the local and regional creative economy is often misunderstood by local and regional policy-makers. They may only target specific stages in the development of the creative process, in particular the start-up phase, consequently becoming ineffective over the longer term. In spite of all the support toward creative 
industries and the positive urban changes occurring in both cities in the last ten years, they are still struggling to be recognised by London-based companies for their creative profile.

Implications for research and policy

In conclusion, Birmingham and Newcastle-Gateshead are only two examples of how the local and regional dimensions interact with the development of the creative economy in England. It is interesting to note that both cities and regions attract creative individuals and firms due to their character as "regions" and due to specific assets: size and easy transportation access for Birmingham and beautiful landscapes and a strong regional creative identity for NewcastleGateshead. However, despite different cultural and economic assets in the potential of developing stronger creative economies both cities face similar challenges: restrictive markets, negative image and strong competition with London. Different local and regional contexts may reveal different features and issues. That is why further comparable research should be encouraged. When looking at our specific case studies, the knowledge pool model developed by CURDS (2001) has been valuable in highlighting the complex set of relations between creative individuals and the place often underplayed in the cluster approach. In particular, both the role of the personal dimension and the wider local and regional infrastructure seem to be important factors in shaping the local and regional creative economy.

The paper suggests potential local and regional enabling and inhibiting factors that could be addressed by national policies. This is especially important as despite ten years of implementation of regional policies in England, regions outside London still struggle to compete with the capital in the development of their creative industries. In addition, some of our findings highlight the key importance of links outside the region, which can often be ignored in favour of a local and regional supply-chain argument. Only considering the relationship between the locality and the activities which take place there and which add value within the local production process can provide a limited perspective (PRATT, 2004a). Therefore, it is crucial to consider the leakages and 


\section{Acknowledgements}

The authors thankfully acknowledge the help and kindness of the creative practitioners who took part in the interviews and gave their time. Caroline Chapain is grateful to the 'Innovation Team, Creative Development, Planning and Regeneration' at Birmingham City Council who commissioned the research on the Birmingham side under the ERDF Creative Knowledge Creative Companies (CKCC) programme. Roberta Comunian also thanks Centre for Urban and Regional Development Studies at the University of Newcastle for hosting her PhD field work in 2005-2006. The authors are grateful to Prof. David Bailey, Chris Collinge, Dr. John Gibney, Dr. Stephen Hall, Prof. Lily Kong, Prof. Alan Murie and Prof. Justin O'Connor and to two anonymous referees of this journal for valuable comments and suggestions. Any errors or omissions remain the authors' responsibility.

\section{Bibliography}

Bailey C., Miles S. and Stark P. (2004) Culture-led Urban Regeneration and the revitalisation of identities in Newcastle, Gateshead and the North East of England, International Journal of Cultural Policy 10, 47 - 65.

BAthelt H. and GlÜCKLER J. (2003) Toward a relational economic geography, Journal of Economic Geography, 3, 117-144. 
BASSETT K., GRIFFITHS R. and SMITH I. (2002) Cultural industries, cultural clusters and the city: the example of natural history film-making in Bristol, Geoforum 33, 165-177.

BAXTER J. and EYLES J. (1997) Evaluating qualitative research in social geography: Establishing 'rigour' in interview analysis, Transactions of the Institute of British Geographers 22, 505 - 525.

Bell, D. and JAYne, M. (2003) Assessing the role of design in local and regional economies, The International Journal of Cultural Policy 9, 285-304.

Brown A., O'CONNOR J. and COHEN S. (2000) Local music policies within a global music industry: cultural quarters in Manchester and Sheffield, Geoforum 31, 437-451.

Brown J., Chapain C., Murie A., Barber A., Gibney J., Lutz J. (2007) From a city of a thousand trades to a city of a thousand ideas. Birmingham, West Midlands. Pathways to creative and knowledge based regions, ACRE report 2.3, AMIDSt, University of Amsterdam, Amsterdam.

Burfitt J. A., Chapain C.A, Collinge C.J., Gibney J., Lutz R. J. and Barber A. R. G. (2005) The Development of the Creative Industries in Birmingham, A project under the Creative Companies, Creative Knowledge Program. Prepared for Birmingham City Council by the Centre for Urban and Regional Studies. School of Public Policy. University of Birmingham.

CoE N. M. (2000) The view from out West: embeddedness, inter-personal relations and the development of an indigenous film industry in Vancouver, Geoforum 31, 391-407.

CoE N. M. (2001) A Hybrid Agglomeration? The Development of a Satellite-Marshallian Industrial District in Vancouver's Film Industry, Urban Studies 38, 1753-1775.

CoE N. M. and Johns J. (2004) Beyond production clusters: towards a critical political economy of networks in the film and television industries, in D. PowER and A. J. SCOTT (Eds.) Cultural industries and the production of culture, pp. 188 -204. Routledge, London.

COMUNiAn R. (2008) Mapping and understanding the role of networks in the local creative economy: the North-East of England. In Association of American Geographers (AAG), Annual General Meeting 13-19 April 2008, Boston - MA. 
Creight-Tyte A. (2005) Measuring Creativity: A case study in the UK's Designer Fashion Sector, Cultural Trends 14, 157 - 183.

CREwe L. (1996) Material Culture: Embedded Firms, Organizational Networks and the Local Economic Development of a Fashion Quarter, Regional Studies 30, 257-272.

CURDS (2001) Culture Cluster Mapping and Analysis. Prepared by CURDS, Centre for Urban and Regional Development Studies for ONE North East, Newcastle Upon Tyne.

DCMS (1998) Creative Industries Mapping Document 1998. Department for Culture, Media and Sport, London.

DCMS (2000) Creative Industries - The regional dimension. Department for Culture, Media and Sport, London.

DCMS (2004) DCMS Evidence Toolkit - DET (formerly, The Regional Cultural Data Framework) Technical Report. Department for Culture, Media and Sport, London.

DRAKE G. (2003) 'This place gives me space': place and creativity in the creative industries, Geoforum 34, 511-524.

DTI (2001) Business Clusters in the UK - A First Assessment, Department for Trade and Industry, London.

ETTLINGER N. (2003) Cultural economic geography and a relational and micro space approach to trusts, rationalities, networks and change in collaborative workplaces, Journal of Economic Geography 3, 145-171.

GARnham N. (2005) From cultural to creative industries, International Journal of Cultural Policy 11, 15-29.

Gibson C., Murphy P. and Freestone R. (2002) Employment and Socio-spatial Relationships in Australia' Cultural Economy, Australian Geographer 33, 173 - 189.

GRABHER G. (2001) Ecologies of creativity: the Village, the Group, and the heterarchic organisation of the British advertising industry, Environment \& Planning A 33, 351-374. 
GRABHER G. (2002) Cool Projects, Boring Institutions: Temporary Collaboration in Social Context. Regional Studies 36, 205 - 214.

GRABHER G. (2004) Learning in projects, remembering in networks? Communality, sociality and connectivity in project ecologies, European Urban and Regional Studies 11, 99 -119.

Henry, N. and PINCH, S. (2000), Spatialising knowledge: Placing the Knowledge Community of Motor Sport Valley, Geoforum 31, 191-208.

JAYNE M. (2005) Creative industries: the regional dimension?, Environment \& Planning C: Government \& Policy 23, 537 - 556.

JEFFCUTT P. (2004) Knowledge Relationships And Transactions in a Cultural Economy: Analysing the Creative Industries Ecosystem, Media International Australia incorporating Culture and Policy 112, 67-82.

JeffCutt P. and Pratt A. C. (2002) Managing Creativity in the Cultural Industries, Creativity and Innovation Management 11, 225-233.

JULIER G. (2005) Urban Designscapes and the Production of Aesthetic Consent, Urban Studies 42, 869-887.

Kong L. (2005) The sociality of cultural industries, International Journal of Cultural Policy 11, 6176.

KRÄTKE S. (2002) Network analysis of production clusters: the Potsdam/Babelberg film industry as an example, European Planning Studies 10, 27 - 54.

LANGE B. (2005) Socio-spatial strategies of culturepreneurs. The example of Berlin and its new professional scenes, Zeitschrift fur Wirtschaftsgeographie 49, 79-96.

LESLEY D. (1997) Abandoning Madison Avenue: The relocation of advertising services in New York City, Urban Geography 18, 568-590.

Lutz J., Chapain C. A., Collinge C., Barber A. and Tice A. (2007) Making the Business Case: Baseline and Growth Study of the Creative Industries in Birmingham. Prepared for Birmingham 
City Council. Centre for Urban and Regional Studies, School of Public Policy, University of Birmingham.

Markusen, A. (2003), Fuzzy Concepts, Scanty Evidence, Policy Distance: The Case for Rigour and Policy Relevance in Critical Regional Studies, Regional Studies 37, 701-717.

Martin, R. And Sunley, P. (2003) Deconstructing Clusters: Chaotic Concept and Policy Panacea, Journal of Economic Geography 3, 5-35.

McRobiIE A. (2002) Clubs to Companies: Notes on the Decline of Political Culture in speeded up Creative worlds, Cultural Studies 16, 516-531.

Minton, A. (2003) Northern Soul: Culture, Creativity and quality of place in Newcastle and Gateshead. DEMOS \& RICS, London.

Molotch H. (1996) LA as product: how design works in a regional economy, in A. J. SCOTT and E. Soja (Eds.) The city: Los Angeles and urban theory at the end of the twenty century, pp. 225275. University of California Press, Berkeley and Los Angeles.

Moss L. (2002) Sheffield's cultural Industries Quarter 20 years on: what can be learned from a pioneering example?, International Journal of Cultural Policy 8, 211-219.

Mossig I. (2004) The Networks Producing Television Programmes in the Cologne Media Cluster: New Firm Foundation, Flexible Specialization and Efficient Decision-making Structures, European Planning Studies 12, 155-171.

NefF G. (2004) The Changing Place of Cultural Production: The Location of Social Networks in a Digital Media Industry, The ANNALS of the American Academy of Political and Social Science 597,134-152.

NESTA (2006) Creating Growth: How can the UK develop world class creative businesses. NESTA, London.

Newman P. and Smith I. (2000) Cultural Production, Place and Politics on the South Bank of the Thames, International Journal of Urban and Regional Research 24, 9-24. 
NORTHERN FILM \& MEDIA (2004) The moving image sector in the North East of England: mapping, benchmarking and economic impact report. Report commissioned to Pembridge Partnership Limited.

O'Connor J. (1999) Definition of Cultural Industries. Manchester Institute for Popular Culture, Manchester Metropolitan University.

O'Connor J. (2002) Public and Private in the Cultural Industries, in T. Johansson and O. SERnHEDE (Eds.) Lifestyle, Desire and Politics: Contemporary Identities, pp. 15 -33. Centre for Cultural Studies, University of Gothenburg.

OAKLEY K. (2004) Not So Cool Britannia: The Role of the Creative Industries in Economic Development, International Journal of Cultural Studies 7, 67-77.

OAKLEY K. (2006) Include Us Out - Economic Development and Social Policy in the Creative Industries, Cultural Trends 15, 255 - 273.

OINAS P. (1999) Voices and silences: the problem of access to embeddedness, Geoforum 30, 351361.

PollaRd J. (2004) From industrial district to 'urban village'? Manufacturing, Money and Consumption in Birmingham's Jewellery Quarter, Urban Studies 41, 173-193.

PORTER M. (1998a) Cluster and the New Economics of Competition, Harvard Business Review 76, 77-91.

Porter M. (1998b) On Competition. Harvard Business School Press, Boston.

PrATT A. C. (1997) The cultural industries production system: a case study of employment change in Britain, 1984-91, Environment and Planning A 29, 1953-1974.

PratT A. C. (2000) New media, the new economy and new spaces, Geoforum 31, 425-436.

PRATT A. C. (2002) Hot jobs in cool places. The material cultures of new media product spaces: the case of the south of market, San Francisco, Information, communication and society 5, 27-50.

Pratt A. C. (2004a) Creative Clusters: Towards the governance of the creative industries production system?, Media International Australia 112, 50-66. 
PRATT A. C. (2004b) The cultural economy: a call for spatialized 'production of culture' perspectives. International Journal of Cultural Studies 7, 117-28.

PrATT A. C. (2004c) Mapping the cultural industries: Regionalization; the example of South East England, in D. PowER and A. J. SCOTT (Eds.) Cultural industries and the production of culture, pp. 19-36. Routledge, London.

RANTISI N. M. (2002) The Local Innovation System as a Source of Variety: Openness and Adaptability in New York City's Garment District. Regional Studies 36, 587-602.

SCOTT A. J. (1994) Variations on the theme of agglomeration and growth: The gem and jewellery industry in Los Angeles and Bangkok, Geoforum 25, 249 - 263.

ScotT A. J. (2000) The Cultural Economy of Cities. Sage, London.

ScotT A. J. (2002) A New Map of Hollywood: The Production and Distribution of American Motion Pictures, Regional Studies 36, 957-975.

ScotT A. J. (2004) Cultural-Products Industries and Urban Economic Development: Prospects for Growth and Market contestation in Global Context, Urban Affairs Review 39, 461-490.

ScotT A. J. (2005) On Holllywood: The place, the industry. Princeton University Press, Princeton.

SHORTHOSE J. (2004) The engineered and the vernacular in cultural quarter development, Capital \& Class 84, 159-178.

STORPER M. (1989) The transition to flexible specialisation in the US film industry: external economies, the division of labor, and the crossing of industrial divide, Cambridge Journal of Economics 13, 273 - 305.

STORPER M. and CHRISTOPHERSON S. (1987) Flexible specialization and regional industrial agglomerations: the case of the U.S. motion picture industry, Annals of the Association of American Geographers 77, 104-117.

TAYLOR C. F. (2006) Beyond Advocacy: Developing an Evidence Base for Regional Creative Industry Strategies, Cultural Trends 15, 3 -18. 
TuROK I. (2003) Cities, Clusters and Creative Industries: The Case of Film and Television in Scotland, European Planning Studies 11, 549-565.

VervaeKe M. and LeFeBVRE B. (2002) Design trades and inter-firm relationship in the Nord-Pas de Calais textile industry, Regional Studies 36, 661-673.

WitTEL A. (2001) Toward a Network Sociality, Theory Culture Society 18, 51-76. 
Creative and cultural sector Authors (date): City - Cluster

PRATT (2000) SILICON ALLEY, NEW YORK

PRATT(2002) SAN FRANCISCO

NeFF (2004) NEW YORK

\begin{tabular}{|c|c|}
\hline \multirow[t]{6}{*}{ Film / TV production } & SCOTT (2002; 2005) HOLLYWOOD \\
\hline & BASSETT et al.(2002) BRISTOL \\
\hline & COE $(2000 ; 2001)$ VANCOUVER \\
\hline & Mossig(2004) ColOGNE \\
\hline & TUROK (2003) SCOTLAND \\
\hline & KRÄTKE (2002) POTSDAM /BABELBERG \\
\hline \multirow[t]{4}{*}{ Design } & MOLOTCH (1996) LOS ANGELES \\
\hline & VERVAEKE AND LEFEBVRE(2002) NORD-PAs DE CALAIS \\
\hline & JULIER(2005) BARCELONA \\
\hline & BELL AND JAYNE(2003) STAFFORDSHIRE \\
\hline \multirow[t]{2}{*}{ Craft / Makers } & POLLARD (2004) JEWELLERY, BIRMINGHAM \\
\hline & SCOTT (1994) JEWELLERY, LOS ANGELES / BANGKOK \\
\hline \multirow[t]{3}{*}{ Advertising } & NEWMAN AND SMITH(2000) LONDON \\
\hline & GRABHER(2001) LONDON \\
\hline & LESLEY(1997) NEW YORK \\
\hline \multirow[t]{3}{*}{ Music } & BROWN ET AL.(2000) MANCHESTER AND SHEFFIELD \\
\hline & MOSS (2002) SHEFFIELD \\
\hline & GIBSON ET AL.(2002) AUSTRALIA \\
\hline \multirow[t]{2}{*}{ Fashion / Clothing } & CREWE (1996) NOTTINGHAM \\
\hline & RANTISI(2002) NEW YORK \\
\hline
\end{tabular}




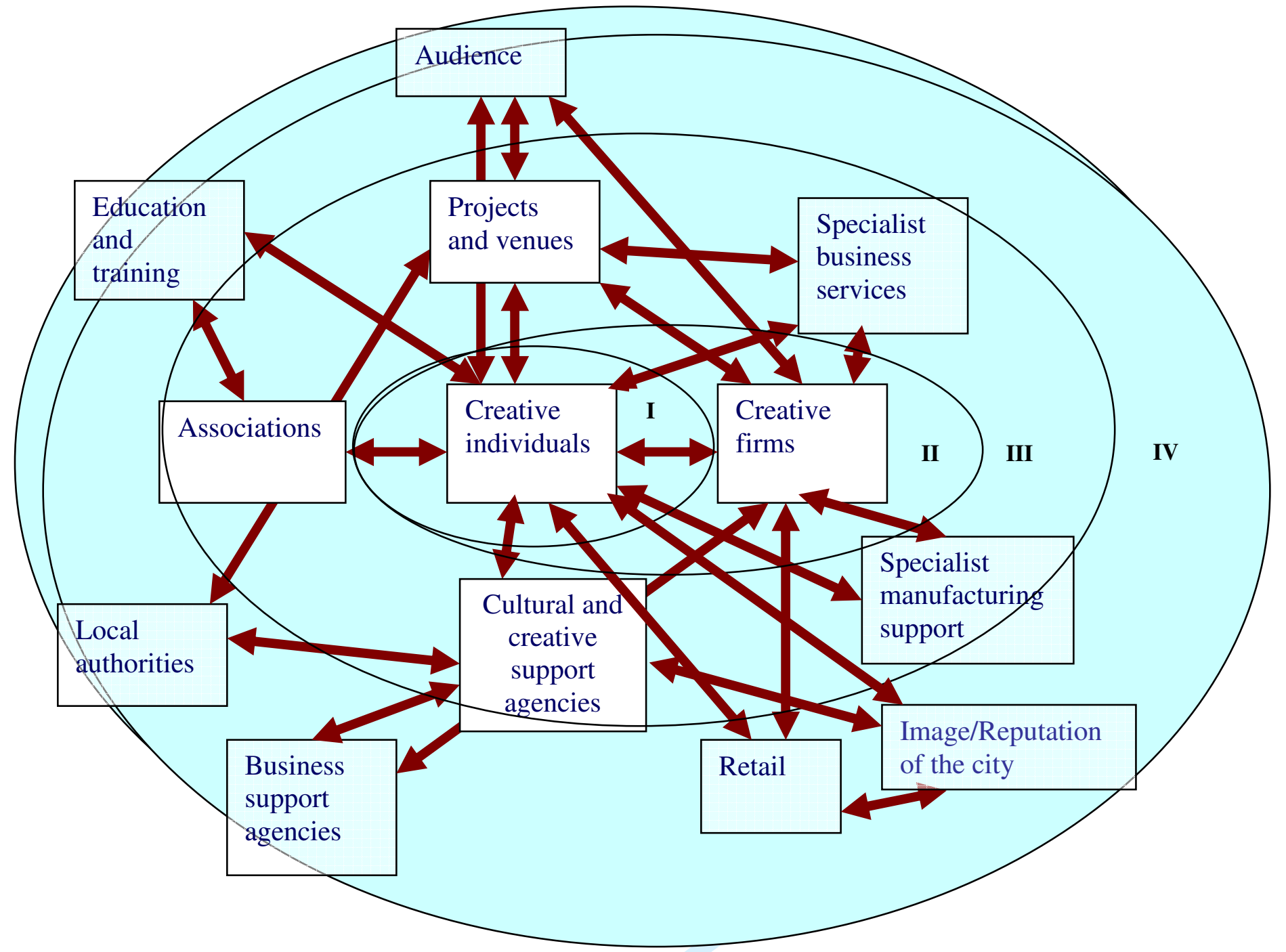

Fig. 1. Adapted from "The Creative Knowledge Pool Model" (CURDS, 2001, p.11). The circles / levels added in the background are an elaboration of the authors. 


\begin{tabular}{|c|c|}
\hline Birmingham & Newcastle-Gateshead \\
\hline $\begin{array}{l}\text { I am from Birmingham born and bred and } \\
\text { fiercely proud of it. (Partner, Advertising) } \\
\text { There is a sense of prosperity. [...] everybody } \\
\text { knows about the new Bullring [...]. It is a sign } \\
\text { of confidence. Quite a strong statement about } \\
\text { what Brum is up to and that it wants to attract } \\
\text { people. (Editor, Publishing Company) } \\
\text { I attended the University of Birmingham and } \\
\text { went on to study further in Paris. Currently, I } \\
\text { am based in Birmingham but I have lived and } \\
\text { worked in France, Germany and Greece. } \\
\text { (Freelance, Performance Theatre.) }\end{array}$ & $\begin{array}{l}\text { I am from here and the North-East is a very } \\
\text { special place (Magazine Editor, Publisher) } \\
\text { I think people underestimate the North-east } \\
\text { culture, it is very deeply rooted in various areas } \\
\text { like the industry that used to be here [...] the lack } \\
\text { of that now has left a bit of a void and some of the } \\
\text { art works have helped to fill in that gap } \\
\text { (Photographer) } \\
\text { The whole bid for the capital of culture was really } \\
\text { important in creating a 'buzz', the investment and } \\
\text { the regeneration, I love the Angel, this buzz has } \\
\text { made it less difficult to come here (Glass Artist) } \\
\text { The quality of life here is undeniable, the ability } \\
\text { to move around quite quickly, geographically [...] } \\
\text { get to the countryside easily and the coast } \\
\text { (Director, TV Company, NG) }\end{array}$ \\
\hline
\end{tabular}

Table 2: Key quotes on the personal reasons for being located in both cities. 
Newcastle-Gateshead

I have found it easier to be creative here than in London because in London there is much more economic pressure on you to just survive (Jewellery Maker)

Advantages are that you kind of stand out a bit in our industry because you are not in a sea of similar companies that are based in the main music scene (Marketing manager, Record label)

The industry, traditionally, has been Londoncentric and Manchester-centric, and Newcastle tends to be out in the sticks [...] as a result we're the poor cousins when it comes to the cultural sector. [...] it's all about money. (Film Maker)

And looking at drama, it offers every location that you ever want. (...) within half an hour we have the castles, the dungeons, the caves, the coasts..." (Director, Film Company)

I came here to the National Glass Centre because the support they were offering [...] (Glass Artist)

The Jewellery Quarter is an ideal location, close to the Jewellery Innovation Centre, the Birmingham customer base and with affordable rental levels. I would not wish to move to another location (Jeweller)

It is easy in terms of communication: we have rail network, airport and motorway network. (Publisher)

If you also count Glasgow, Edinburgh and Liverpool and Manchester. If you draw a circle of two hours around Newcastle I think we are still quite central. (Freelance designer)

If I was working in London a copyrighter is regarded as an important part of the creative process, up here it is not, because it is just words, clients are not sophisticated in the North-East [...] as far as they are concerned it is just words (Freelance Copywriter)

Table 3: Key quotes on the operational advantages and disadvantages of being located in both cities. 
Newcastle-Gateshead

I think it opens all sorts of doors [...] the process of starting up a business would have been completely different had I not been in this building, [...] it is vitally important to be surrounded by other people in the same sector (Design and Maker)

Birmingham City Council involves informal attempts to bring creative sectors together. I attend the Birmingham Creative Partnership Board. (Manager, TV Company)

Business is secured largely by "word of mouth', through local connections in the Jewellery Quarter, via longstanding traditional customers and via family connections. (Jeweller)

We take on contract staff, who mainly come from word of mouth, and there are many well known people in Birmingham. (Architecture CEO)

Lots of work is done informally and this is encouraged by a dining club of like minds. (Director, Dance Company)

Our company works locally, regionally, nationally, especially in its artists consultancy role, and internationally (Director, Dance Company)

I make some use of formal industry events to build up the business networks and profile. (Director, Design Company)

There is not that many jobs in the North East and lots of people goes to people they already know, it is an insular community. (Freelance Cartoonist)

Sometimes you're talking to all of the same people all of the time, and that's not necessarily the most conducive way to developing the best practice, so there's a sort of constant recycling of the same people's ideas. (Manager, Performing Arts Venue)

Table 4: Key quotes on the role of networking in both cities. 


\begin{tabular}{|l|}
\hline Birmingham \\
I love what is going here with the regeneration, \\
which started with the NEC, then moved on \\
with the Custard factory and then the Bullring. \\
It is vibrant. (Director, Advertising)
\end{tabular}

The airport has created new links to new countries so its easier to bring people in now (Director, Screen Media Company)

We collaborate with a vast range of city arts organisations. After performing, our second most important activity is education. (...) We have links with the University of Birmingham via its MA course. (Director, Dance Company)

We have a major commitment to shift our business out of London and Birmingham is a key production hub with the University of Central England, the University of Birmingham and Matthew Boulton. (Manager, TV Company)

Our client split is about $65 \%$ corporate/public organisations and $35 \%$ creative. The creative work is fun, the organisational clients pay the bills. (Designer)

Birmingham City Council is a very important source of support to cultural organisations but the majority of its funding goes to the very big flagship companies (Director, Dance Company)

Within the region people and organisations want things for free but this is a creative paradox - these same agencies and people expect to see a healthy commercial creative sector grow - how can you do this if creative people don't get paid? (Director, Screen Media.)

There appeared to be plenty of money for startups in the city but this was accompanied by a difficulty in moving on to the growth stage (Founder, Music Company.)

The challenge simply put is: "We don't know how to find clients and they don't know how to
Newcastle-Gateshead

Things like the Sage have been a very positive influence on feeling that $I$ am in a creative community, just seeing the different and diverse music [...] Tyneside Cinema is my lifeline, without that I really couldn't stay in the region (Film Maker, NG)

In the last ten years there has been a huge expansion in the creative industries which has facilitated organisations and establishing networks and a lot of innovative thinking from people in the funding agencies (Freelance, Writer consultant)

The amount of support that was available in essence was incredible [...] we achieved funding through Princes Trust, through Tyne and Wear development, through Newcastle Council, through the Arts Council itself. We had help with brands and developments from BusinessLink etc; in essence it was a big amount of help we achieved. (Director Music Company and label).

People are very supportive and enthusiastic because it's all new, so you are at the start, you know it's going to take a little while, but if you look at the Ouseburn, you know it's going to boom. (Freelance Designer)

The problem is they see a disperse group of people fragmented working in small places they do not see a big company like Nissan, they think economically the sector is insignificant, they cannot understand the dynamic of it (Director, TV company)

They should be putting the main focus actually educating people or helping people understand (the importance of design) showing the business benefits, that would do more than any grant that they give out to design businesses (Director, Design Company)

There is still this perception from our folks in London, that Newcastle is hundreds of miles away, you know, do you really want to go there? (Director, Film Company) 
When you reveal where you are, they are absolutely amazed that the sort of things we are doing could be done in a place so provincial on the edge and so far north, it is a very strange attitude of people from London. (Freelance writer consultant) image and the accent, which puts people off. (Founder, Music Company.)

Some companies tend to take 0800 telephone number to mask their geographical location. (Designer) 


\begin{tabular}{|c|c|c|}
\hline & Birmingham & Newcastle-Gateshead \\
\hline \multicolumn{3}{|c|}{ Personal dimension } \\
\hline Similarities & \multicolumn{2}{|c|}{$\begin{array}{c}\text { City is "buzzing" } \\
\text { Some individuals studied there } \\
\text { Some individuals are there because this is slightly backyard }\end{array}$} \\
\hline Specificities & $\begin{array}{c}\text { Born and bread } \\
\text { Easy access due to transportation }\end{array}$ & $\begin{array}{l}\text { Quality of life } \\
\text { "Creative place" }\end{array}$ \\
\hline \multicolumn{3}{|c|}{ Operational advantages and disadvantages } \\
\hline Similarities & \multicolumn{2}{|c|}{$\begin{array}{l}\text { Love/hate relationship with London: distinctive, } \\
\text { less competition but problem of image with the perception that quality is in } \\
\text { London and most of the work is there }\end{array}$} \\
\hline Specificities & $\begin{array}{c}\text { Size of the city } \\
\text { Important Black and ethnic minorities } \\
\text { community } \\
\text { Jewellery cluster } \\
\text { Easy access and close to London } \\
\text { (Train/Car) }\end{array}$ & $\begin{array}{l}\text { Cluster in visual arts, writing and music } \\
\text { Remote from London but increased access } \\
\text { (airport) and close to Manchester, } \\
\text { Scotland... }\end{array}$ \\
\hline \multicolumn{3}{|c|}{ Networking } \\
\hline Similarities & \multicolumn{2}{|c|}{$\begin{array}{l}\text { Importance of local and regional social networks } \\
\text { Individuals belong to a mix of formal and informal networks } \\
\text { Multi-scale networks }\end{array}$} \\
\hline Specificities & International connections & Lock in effect \\
\hline \multicolumn{3}{|c|}{ Regional infrastructure } \\
\hline Similarities & \multicolumn{2}{|c|}{$\begin{array}{l}\text { Positive role of regeneration and flagship projects } \\
\text { Active public support } \\
\underline{\text { Some incomprehension from the public sector }} \\
\underline{\text { Problem of image }}\end{array}$} \\
\hline Specificities & Importance role of the universities & Strong regional identity \\
\hline
\end{tabular}

Note: Underlined format denotes inhibiting factors.

Table 6: Factors enabling or inhibiting the development of creative industries in Birmingham and Newcastle-Gateshead - similarities versus specificities. 
Endnotes

\begin{abstract}
1 Although Newcastle and Gateshead are two distinct municipalities, the joint bid for the European Capital of Culture title and the joint cultural strategy adopted suggests the need to consider them as a single metropolitan area, especially when looking at culture and creative economy in the NorthEast region.
\end{abstract}

2 For an in-depth analysis of the difficulties and limits of the national and regional estimates refer to DCMS (2004), Creight-Tyte (2005) and Taylor (2006).

3 For an overview of the regional documents addressing CCIs see JAYNE, 2005 and OAKLEY, 2006. 4 The research used the DCMS (1998) definition of creative industries and was made up of four main components: a review of the academic and policy literature, an analysis of local secondary statistical data, a survey of 349 creative industry firms in Birmingham, and a programme of 31 detailed company/organisation case studies. The research was phased within the overall CKCC programme and conducted between 2002 and 2005.

5 The definition adopted was based on DCMS, but aimed at addressing the importance of networks and relations. Therefore, the public sector (both in terms of publicly subsidised cultural institutions and in terms of policy makers and support agencies) has been included in order to understand its wider connection with the creative practitioners in the $\mathrm{PhD}$ research.

6 The interviews (31 for Birmingham and 33 for Newcastle-Gateshead) were analysed using NVivo7 and by coding common and specific themes related to our broader research questions.

7 Newsweek Atlantic Edition on $2^{\text {nd }}$ September 2002 wrote "Newcastle-Gateshead listed as one of the world's eight most creative cities".

8 The first research commissioned from the University of Newcastle (CURDS, 2001) aimed to map the strengths and weaknesses of the sector but specific strategies have been developed since then. In 2007 new research was commissioned by the RDA, One North East, specifically to investigate the 
'Commercial Creative Sector' : “ONE North East wishes to commission consultants to work with the Agency to identify strategic market failures within key components of the creative industries sector in the North East" (www.onenortheast.bravosolution.com, last accessed 30 May 2007). 9 The information can be found on-line and includes a map of the city cultural quarters http://www.visitnewcastlegateshead.com/cultureQuarters.php\# (accessed on $4^{\text {th }}$ June 2007). 


\section{Tables and Figures}

\begin{tabular}{|c|c|}
\hline Creative and cultural sector & Authors: City - Cluster \\
\hline \multirow{3}{*}{ New media / New technologies } & PRATT (2000) Silicon AlLEY, NEW YORK \\
\hline & PRATT(2002) SAN FRANCISCO \\
\hline & NEFF (2004) NEW YoRK \\
\hline \multirow[t]{6}{*}{ Film / TV production } & SCOTT $(2002 ; 2005)$ HOLLYWOOD \\
\hline & BASSETT et al.(2002) BRISTOL \\
\hline & COE $(2000 ; 2001)$ VANCOUVER \\
\hline & MOSSIG(2004) COLOGNE \\
\hline & TUROK (2003) SCOTLAND \\
\hline & KRÄTKE (2002) POTSDAM /BABELBERG \\
\hline \multirow[t]{4}{*}{ Design } & MOLOTCH (1996) LOS ANGELES \\
\hline & VERVAEKE AND LEFEBVRE(2002) NORD-PAs DE CALAIS \\
\hline & JULIER(2005) BARCELONA \\
\hline & BELL AND JAYNE(2003) STAFFORDSHIRE \\
\hline \multirow[t]{2}{*}{ Craft / Makers } & POLLARD (2004) JEWELLERY, BIRMINGHAM \\
\hline & SCOTT (1994) JEWELLERY, LOS ANGELES / BANGKOK \\
\hline \multirow[t]{3}{*}{ Advertising / } & NEWMAN AND SMITH(2000) LONDON \\
\hline & GRABHER(2001) LONDON \\
\hline & LESLEY(1997) NEW YORK \\
\hline \multirow[t]{3}{*}{ Music } & BROWN ET AL.(2000) MANCHESTER AND SHEFFIELD \\
\hline & Moss (2002) SHEFFIELD \\
\hline & GIBSON ET AL.(2002) AUSTRALIA \\
\hline \multirow[t]{2}{*}{ Fashion / Clothing } & CREWE (1996) NOTTINGHAM \\
\hline & RANTISI(2002) NEW YORK \\
\hline
\end{tabular}

Table 1: Overview of the most important studies of CCIs clusters 


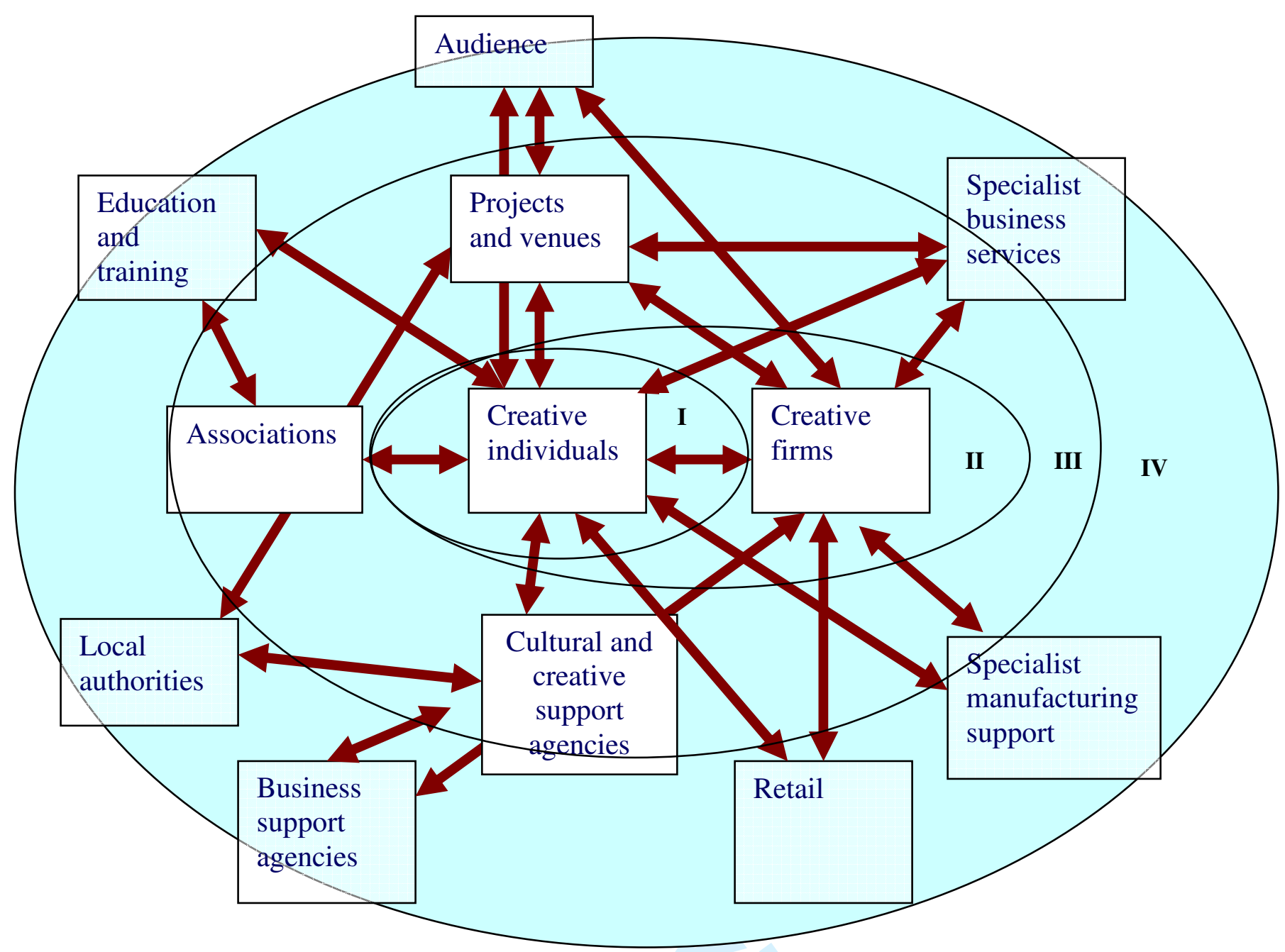

Fig. 1. The Creative Knowledge Pool Model (CURDS, 2001, p.11). The circles / levels added in the background are an elaboration of the model by the authors. 